\title{
Important Mycoses in Children in South America
}

\author{
Fabianne Carlesse $^{1} \cdot$ Adriana Maria Paixão de Sousa da Silva $^{2} \cdot$ Maria Elena Santolaya $^{3}$
}

Published online: 20 February 2016

(C) Springer Science+Business Media New York 2016

\begin{abstract}
Invasive fungal disease (IFD) is an important infection with high rates of morbidity and mortality in hospitalized patients. Data on incidence, risk factors, and mortality of IFD in the pediatric population, mainly in South America, are scarce. The aim of this paper was to review the literature about the most important IFD in pediatrics in South America. We searched three electronic databases (Medline, Lilacs, and Cochrane databases) for studies published between 2012 and 2015; case reports and editorial were excluded. Twenty-two articles were found on Candida spp. infections; eight on Paracoccidiodes spp.; two on Cryptococcus spp.; and one on Aspergillus spp. Candida albicans was the main agent, followed by Candida parapsilosis in pediatric population. Paracoccidioides spp. had a prevalence ranging from 2.3 to $35.3 \%$ with ages between 11 and 29 years, malnutrition, and hepatic involvement related to the worst prognosis. Cryptococcus spp. showed a prevalence of $2.6 \%$ in under 16 years old, with cryptococcal meningitis most observed, mainly by Cryptococcus neoformans (94.1\%). Aspergillosis and other mold infections, as zygomycosis and fusariosis
\end{abstract}

This article is part of the Topical Collection on Pediatric Fungal Infections

Fabianne Carlesse

fabiannecarlesse@graacc.org.br

1 GRAACC-Instituto de Oncologia Pediátrica, Universidade Federal de São Paulo (UNIFESP), São Paulo, Brazil

2 Universidade Federal de São Paulo (UNIFESP), São Paulo, Brazil

3 Infectious Diseases Unit, Department of Pediatrics, Hospital de niños Dr. Luis Calvo Mackenna, Faculty of Medicine, Universidad de Chile, Santiago, Chile occurring mostly in immunocompromised children, related with relevant morbidity and mortality in this population.

Keywords Mycoses · Children · South America · Fungal infection $\cdot$ Pediatric fungal infections

\section{Introduction}

Invasive fungal disease (IFD) is a relatively common and potentially lethal infection in hospitalized children, especially in patients with serious underlying diseases such as hematological malignancies or critically ill patients hospitalized in intensive care units (ICUs), that prolong hospital stay, have elevated morbidity and mortality rates, and increase medical care costs. Multiple surveillance networks have documented a high incidence of pediatric fungal bloodstream infections [1] especially in susceptible hosts $[2,3]$. IFD are the leading infectious cause of death in children with cancer or following an organ or hematopoietic stem cell transplant (HSCT) [4, 5]. The case fatality rate associated with pediatric fungal sepsis is $13 \%$, the second highest rate of all causes of sepsis in children in USA [6].

Studies describing the epidemiology, clinical and laboratory characteristics of IFD have been performed mostly in adult populations [7]. There are some differences in risk factors and features for IFD between adults and children, and the use of adult data to manage these infections in pediatric setting may be inappropriate. Apart from this, the incidence and epidemiology of IFD may differ significantly depending on the geographic region [8]. Data on incidence, risk factors, and mortality of IFD in the pediatric population in South America are scarce. The knowledge of these epidemiological differences to implement appropriate strategies of prevention, diagnosis, and therapy is noteworthy. The aim of this paper is to review the 
literature about the most important IFD in pediatrics in South America.

\section{Methods}

Three electronic databases were searched (Medline, Lilacs, and Cochrane databases) for studies published between 2012 and 2015 with the following MeSH terms: invasive mycoses, mycoses, invasive fungal infection, yeast infection, mold infection, Candida infection, pediatric fungal infections, children, America, and South America. There were no language restrictions for these searches.

For inclusion, the studies had to have results of IFD in pediatric patients (0 to 18 years old) from South America. Case reports and editorials were excluded (Fig. 1).

Of the studies identified in the updated review, 22 were on Candida spp. infections [8-29] (five articles only in neonatal patients), 8 on Paracoccidiodes spp. [30-37], 2 about Cryptococcus spp. [38, 39], and 1 on Aspergillus spp. [40]. The other selected studies were about the following topics: one epidemiological descriptive study [41], one identified risk factors associated with IFD in patients with cancer [42], one about prophylaxis [43], and one related with the environment as a source of mold infections in pediatric patients with cancer [44].

Main studies included in this revision are shown in Table 1 (candidiasis, paracoccidiodomicosis, cryptoccocosis, aspergillosis, and others)

\section{Candida spp.}

Candida spp. is a commensal microorganism that naturally inhabits various sites in the human body (including the

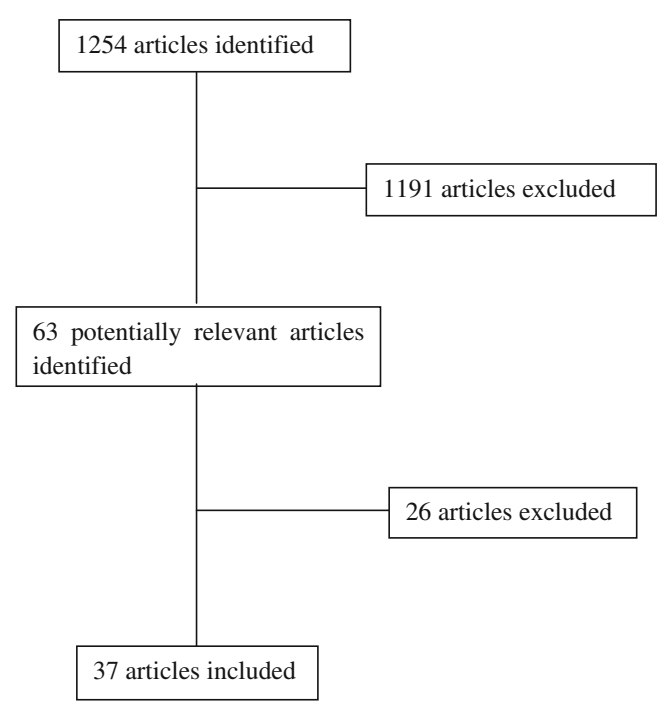

Fig. 1 Flow diagram for invasive fungal disease in South America update review gastrointestinal and respiratory tracts) and in part of the vaginal and urethral microbiota. These microorganisms can become pathogenic as a result of alterations in host defense mechanisms or breakdown of anatomical barriers - situations that are common in hospitalized patients who receive antibiotics or undergo frequent invasive procedures. Candidemia often occurs in patients admitted to neonatal or surgical ICUs [46].

Candida species are the third most common cause of pediatric health care-associated bloodstream infection in the USA and Europe. The attributable mortality from invasive candidiasis in children is $10 \%$, and invasive candidiasis is associated with prolonged hospital stay and increased costs [47]. Inappropriate antifungal therapy and the occurrence of infections by resistant species can impact mortality rate.

The epidemiology of such infections varies among different geographic regions and even between medical centers within the same region with temporal variability [48-51]. The Global Antifungal Surveillance Program, ARTEMIS DISK, analyzed a total of 256,882 Candida isolates obtained from 142 medical centers in Asia, Latin America, Europe, Africa, and North America between 1997 and 2007, showing that the most common species globally was Candida albicans (65.3\%), followed by Candida glabrata (11.3\%), Candida tropicalis (7.2), Candida parapsilosis (6.0\%), and Candida krusei $(2.4 \%)$. These five Candida spp. are important worldwide, but their frequency varied significantly according to the setting $[50,51]$.

Little is known about the epidemiology of candidemia in South America, especially in pediatric patients. Currently, there are 22 studies about this infection which include children [8-29]. From these, only three included exclusively pediatric patients $[14,22,26]$ and from these two followed patients with candidemia $[22,26]$ and only one analyzed samples of $C$. parapsilosis from blood [14], 11 studies included adult and pediatric patients [8, 10-13, 15, 16, 18, 23, 24, 27], 5 studied included only neonates [19-21, 28, 29], 3 were articles about review [25] and recommendations [21, 28], 1 did not informed the age of the patients [16], and 1 was on samples collected from health professionals and the environment [9] (Appendix 1).

C. albicans was reported as the most common species causing candidemia an epidemiological shift toward nonalbicans [51]. In Brazil and some other countries in Latin America, C. parapsilosis is responsible for 20-30\% of nosocomial candidemias in general population [52].

Analyzing the two studies performed in Latin America (LA) which enrolled only pediatric patients, the first was a prospective, multicenter study of active surveillance candidemia in seven countries in LA. This study enrolled 302 patients under 18 years, 89 neonates and 213 children during a 2-year period. Non-albicans Candida species predominated in neonates and children; $C$. albicans alone was 


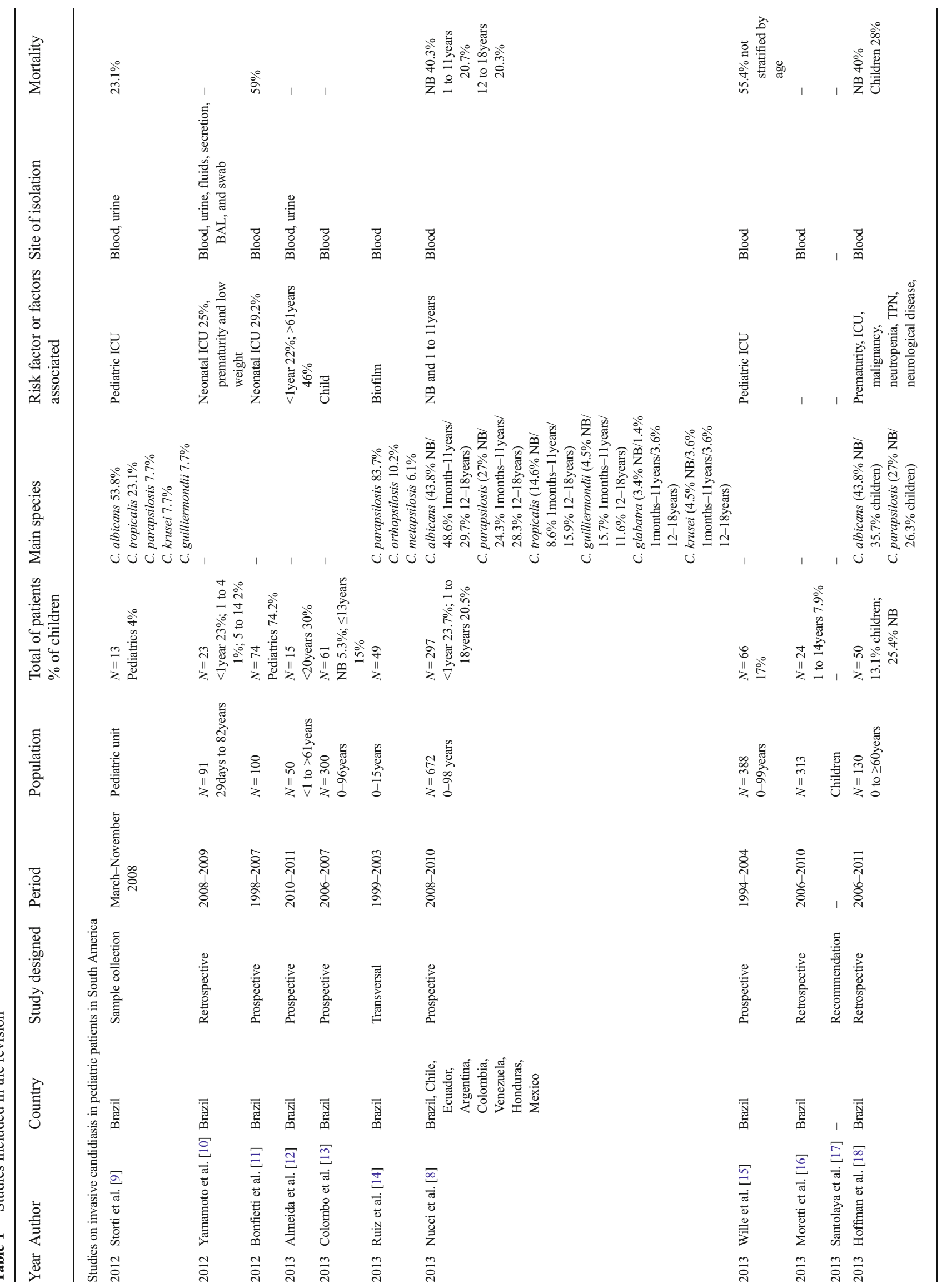




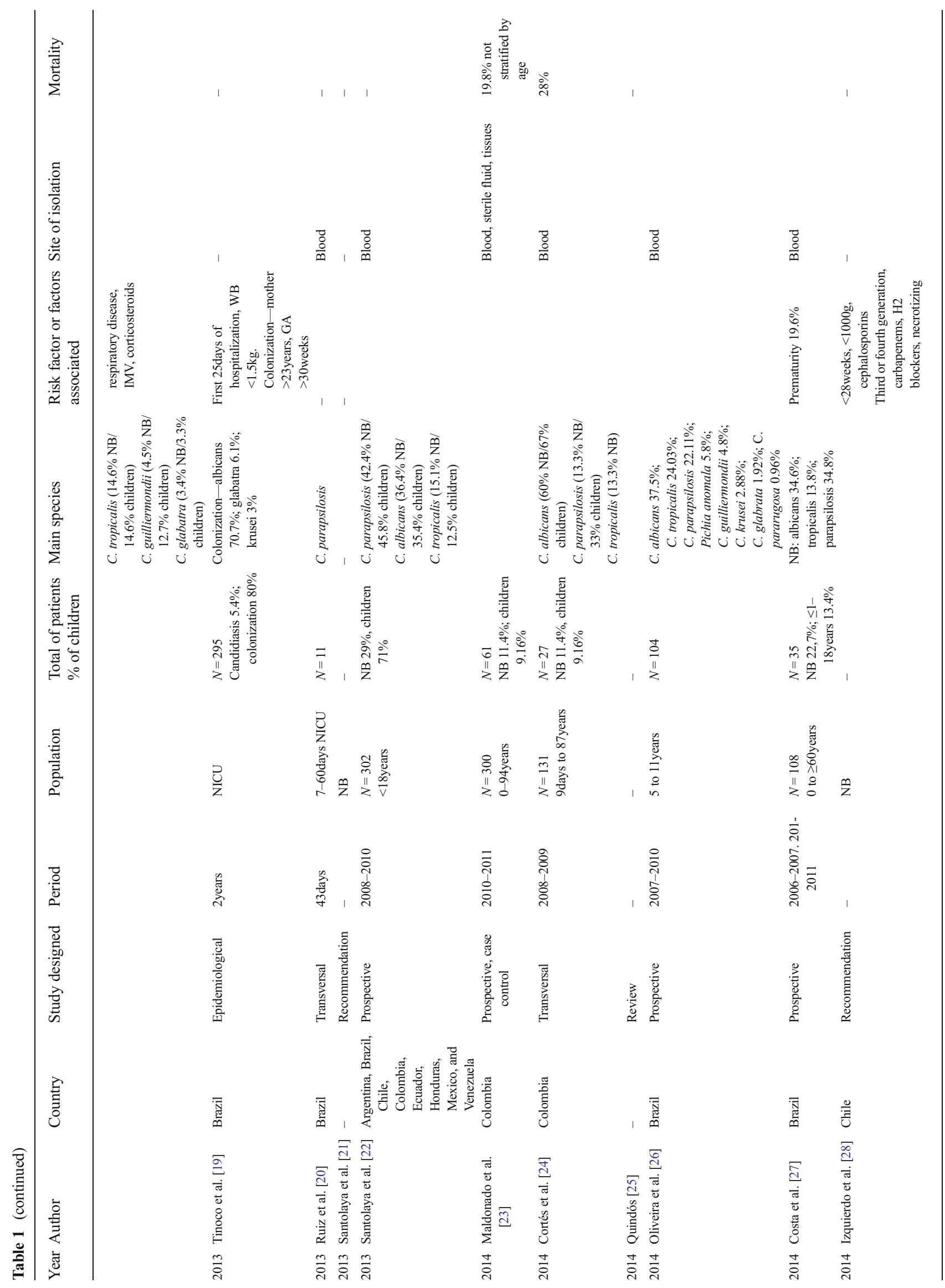




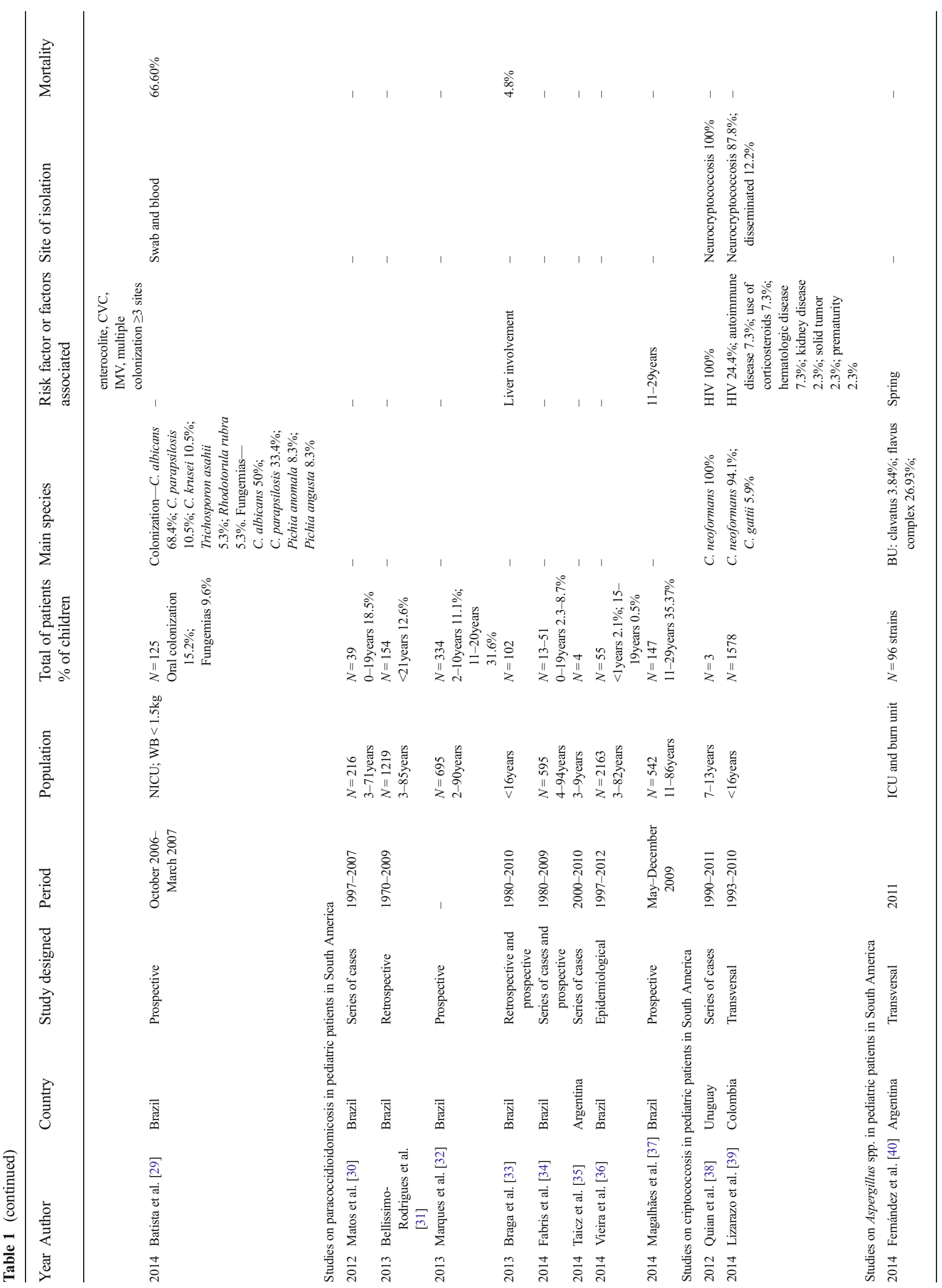




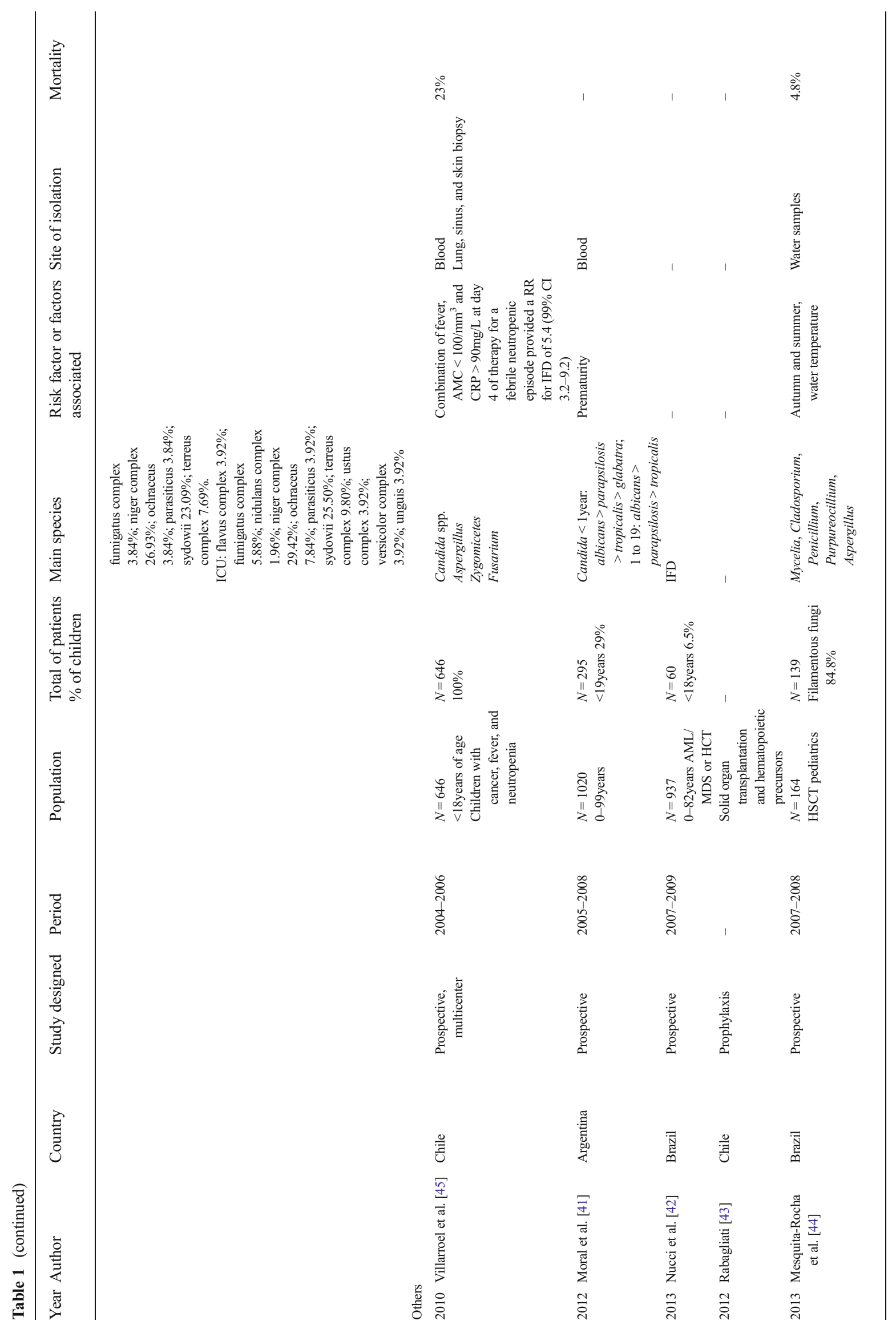


the main specie ( $43.8 \%$ neonates and $35.7 \%$ children), followed by $C$. parapsilosis ( $27 \%$ neonates and $26.3 \%$ children) [8]. Comparing this study with the other largest study published in 2012 by the International Pediatric Fungal Network, which enrolled 221 pediatric patients with invasive candidiasis (25 neonates and 196 children) in the USA, Europe, and Asia over a 5-year period from 2007 to 2011 [53], the two main epidemiological differences are the high frequency of $C$. tropicalis and the low frequency of C. glabrata in LA.

Another study from LA, performed in Brazil, analyzed the frequency of yeasts of the genus Candida over a 4-year period, isolated from 104 patients from 5 to 11 years of age, admitted to a public hospital of the city of Sao Paulo, Brazil. In this study, non-albicans species predominated (63.5\%) and C. tropicalis was slightly more frequent than $C$. parapsilosis ( 24.03 and $22.11 \%$, respectively). On the contrary in LA study, C. parapsilosis was more frequent than $C$. tropicalis (26.3 vs $14.6 \%$ ) [26].

This high prevalence of C. parapsilosis in pediatric patients could be explained by the fact that this species is related to prematurity, presence of central venous catheters, use of total parenteral nutrition [53], and the use of mechanical ventilation [11]. The high prevalence of C. parapsilosis and C. tropicalis as etiologic agents of candidemia in LA has been recorded in other studies which include children and adults $[52,54]$. Candidemia by $C$. tropicalis related with a worse prognosis compared with candidemia by other species in neutropenic patients [11].

Anatomical and physiological differences between the pediatric and adult patients change the susceptibility to infections caused by different species of Candida, which therefore influences the antifungal treatment approach, including issues related to the toxicity of the drugs, pharmacokinetic, and dosage [55]. Data regarding the pattern of resistance of etiologic agents is a powerful tool to guide prophylactic, preemptive, and empiric antifungal therapy [56, 57]. Bonfietti et al. in 2012 evaluated the incidence and susceptibility profile of Candida spp. causative agents of bloodstream infections in a Brazilian tertiary care hospital. They found that C. albicans, C. parapsilosis, and C. tropicalis isolates presented high susceptibility to all antifungal agents tested. The highest fluconazole MICs were observed for $C$. parapsilosis isolates from two patients who were successfully treated with amphotericin $\mathrm{B}$ or fluconazole monotherapy [11]. Recommendation for antifungal therapy in neonates and children with IC in LA is described in Table 2.

\section{Paracoccidioidomycosis}

Paracoccidioidomycosis (PCM) is a systemic infection caused by the dimorphic species of fungus Paracoccidioides brasiliensis or Paracoccidioides lutzii which can exist as a mycelia stage and yeast [58]. The mycelia form is found in nature at temperatures between 18 and $25{ }^{\circ} \mathrm{C}$ and produces spores or yeast-like conidia which may cause infections. Spores inhaled by susceptible hosts are converted into yeast in the tissues. By inhalation, spores target the lungs and later on reach any systemic structure through the lymphatic or blood stream, especially affecting skin, mucus membranes, lymphatic tissue, and adrenal glands [59,60]. Traumatic inoculation, in which the fungus settles on the skin mucosa, can also occur. In most individuals, the disease is self-limited and asymptomatic because of appropriate cellular immune responses [61].

The distribution of this disease is heterogenous showing high and low endemicity in different areas in accordance with climate and the environmental condition in the region. In LA, PCM is considered one of the most important systemic mycoses [36], with Brazil, Venezuela, and Argentina the countries with the greatest number of cases. Over than $80 \%$ of Paracoccidioidomycosis cases worldwide are from Brazil where PCM is the eighth leading cause of death from chronic infectious and parasitic diseases with the highest mortality rate among systemic mycoses with a mean annual mortality rate from 1980 to 1995 was 1.45/million inhabitants [62]. Reports of cases in nonendemic areas are related to people who had lived or visited endemic areas before the beginning of signs and symptoms of the disease [58].

The disease exhibits many clinical presentations, which may be roughly classified into two forms: acute/subacute and chronic. Diversity of clinical presentation has been attributed to the enhanced pathogenicity of some $P$. brasiliensis strains and particularly to host factors that modulate the immune response against the fungus [63, 64].

This infection is more commonly acquired between the first and second decades of life. Progression to the systemic form in this period of the life is rare, between the third and fifth decades of life, the disease is activated, causing the chronic form of PCM [65]. Children and young adults most frequently present with acute/subacute form of the disease (juvenile type), which is a more widespread disease, involving the lymphohematopoietic system (mainly liver) [66, 67]. Older patients generally have a chronic form of the disease (adult type), which affects primarily the lungs and upper airway [60]. Another factor that is important to note is the decrease of the disease in females as they get older. In the prepuberal age, PCM has been known to occur in similar proportions in boys and girls, with a gender ratio of 1.7:1.0. After menarche, women become less susceptible to PCM due to the presence of estrogens, which slowly inhibits the transformation of filamentous phase, the infective, pathogenic yeast phase. In this way, the chronic form is much more prevalent in men, with a gender ratio of 15:1 [68,69].

In our review, we found eight articles of PCM, mainly from Brazil (seven) [30-34, 36, 37] and one from Argentina [35]. 


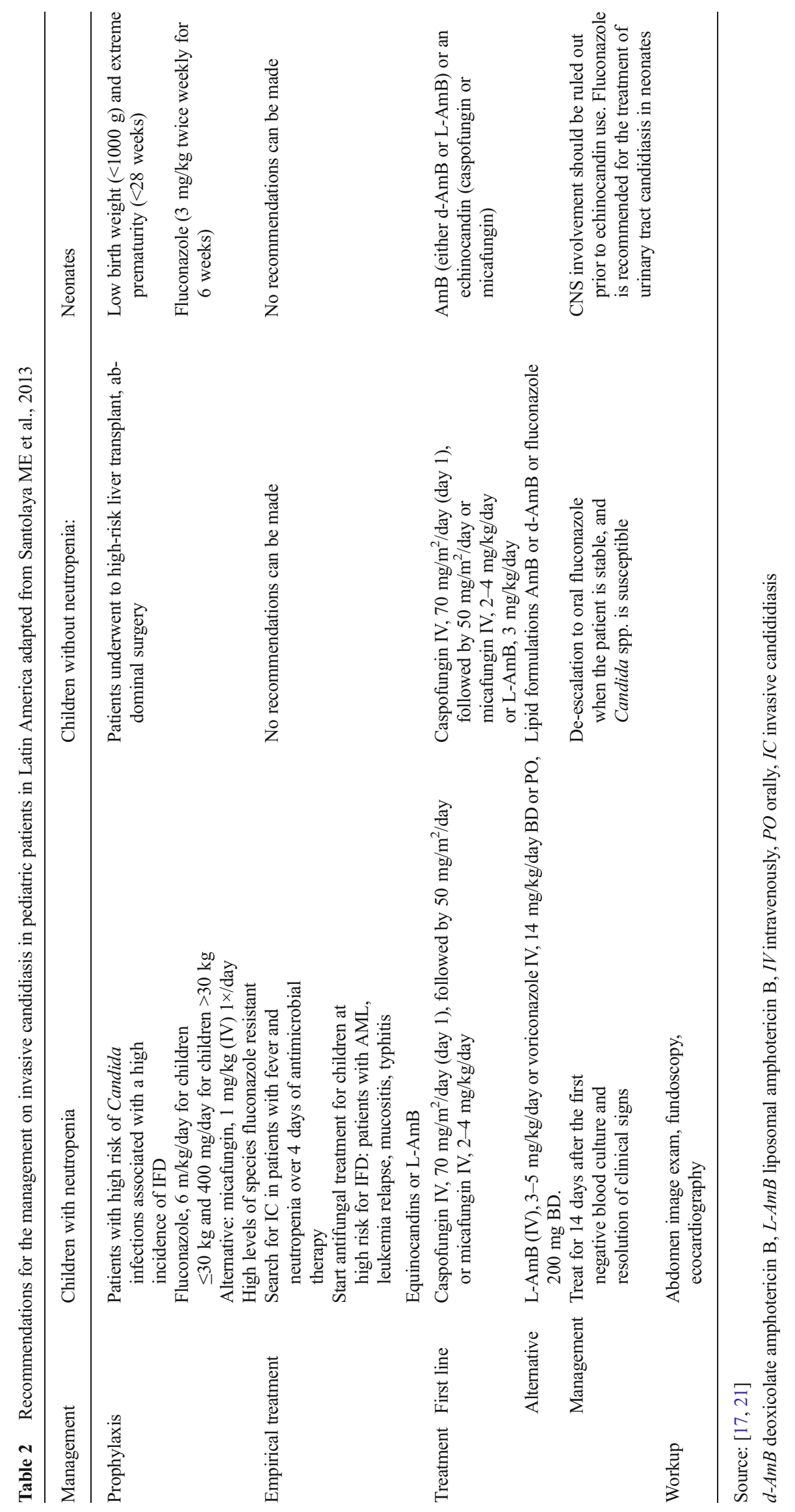


From these, four were prospective studies [32-34, 37], one retrospective [31], two case series [30,35], and one descriptive [36] (Appendix 2). The described prevalence of this disease from 0 to 29 years ranged from 2.3 to $35.3 \%$. Three variables were related to a worse prognosis: age between 11 and 29 years, malnutrition, and hepatic involvement [33, 37]. Major clinical manifestations were generalized lymphadenopathy $(95.1 \%)$, weight loss $(82.9 \%)$, fever (78 \%), asthenia (63.4\%), splenomegaly (58.5\%), pallor (56.1\%), and increased abdominal circunference; $40.1 \%$ had liver involvement with hepatomegaly detected by physical examination in $68.3 \%$ of them [33]. Anemia, leukocytosis, eosinophilia, hypoalbuminemia, hypergamma globulinemia, and increased erythrocyte sedimentation rate (ESR) were the most frequent laboratory findings [33, 37].

The definitive diagnosis was made by histopathological findings in most cases, followed by culture [33, 35]. Two studies evaluated the intradermal reaction (gp43) and showed a poor sensitivity; the exam was positive in 35.4 to $42.7 \%$ of patients between 0 to 29 years of age. None had clinical manifestations [32, 37].

The treatment of PCM includes supportive care and specific antifungals. P. brasiliensis is susceptible to the majority of antifungals: amphotericin B, azoles: fluconazole, itraconazole; ketoconazole, voriconazole, and sulfametoxazole/trimethoprim (TMT/SMX) [61].

Limited data exists comparing the different therapeutic approaches. Itraconazole is recommended for the mild forms due the short time required to control the disease. Patients with severe disease or intolerance to azoles must receive amphotericin $\mathrm{B}$ or TMT/SMX intravenously as inpatient. TMT/SMX was the main drug used in children younger than 10 years old due to the simple administration and tolerance [60].

Voriconazole can be recommended for patients with central nervous system (CNS) involvement due to its effectiveness [60].
In a clinical and laboratory study on pediatric patients with and without hepatic involvement, trimethoprim-sulfamethoxazole was the main drug used (26/41). An association with amphotericin B, ketoconazole, or itraconazole was necessary in $13 / 41$ cases. The remaining patients $(n=2 / 41)$ received a single drug treatment with amphotericin B [33]. Another pediatric series from Argentina used amphotericin B as first choice (3/4) because of severity of the disease followed by itraconazole to complete treatment. All patients survived [35]. The duration of treatment is around 12 months and depends on clinical and serological response [60]. Recommendation for antifungal therapy in children with paracoccidiodomicosis is described in Table 3.

\section{Cryptococcosis}

Cryptococcosis is a systemic fungal disease associated with high lethality. It is caused by Cryptococcus spp. which is an encapsulated fungus that was considered an unusual pathogen before 1955 and became a frequent opportunistic microorganism worldwide, as the population of immunocompromised people increased [70]. Two species of Cryptococcus are the most relevant to human health: Cryptococcus neoformans and Cryptococcus gattii. The first has worldwide distribution and is related to pigeon droppings, being more frequent in patients with HIV/AIDS; by contrast, $C$. gattii is mainly distributed in trees as Eucalyptus camaldulensi of tropical and subtropical regions [71].

After the inhalation of viable airborne spores of these yeasts directly from the environment, Cryptococcus spp. invades the lung tissue and then a hematogenous dissemination occurs, with a predisposition for the CNS [72]. However, there are observations suggesting that infections by Cryptococcus spp. can be asymptomatic and frequent in the early years of life [73]. The disease may occur in immunocompetent

Table 3 Recommendations for management on paracoccidiodomicosis in pediatric patients adapted from Shikanai-Yasuda MA, 2006

\begin{tabular}{|c|c|c|c|c|}
\hline Clinical Presentation & Drug & & Dosage & Duration \\
\hline \multirow[t]{2}{*}{$\begin{array}{l}\text { Mild and moderate } \\
\text { form - outpatients }\end{array}$} & First line & Trimethoprim/sulfametoxazole & $\begin{array}{l}\text { Trimethoprin, } 8 \text { to } 10 \mathrm{mg} / \mathrm{kg} \\
\text { and sulfametoxazole, } 40 \\
\text { to } 50 \mathrm{mg} / \mathrm{kg}(\mathrm{PO}) 12 / 12 \mathrm{~h}\end{array}$ & $\begin{array}{l}\text { 12months on mild } \\
\text { forms and } 12 \text { to } 24 \text { months } \\
\text { on moderate forms }\end{array}$ \\
\hline & Alternative & Itraconazole & $\begin{array}{l}\text { Weighing }<30 \mathrm{~kg} \text { and }> \\
5 \text { years old } \\
5 \text { to } 10 \mathrm{mg} / \mathrm{kg} / \text { day }(\mathrm{PO})\end{array}$ & $\begin{array}{l}6 \text { to } 9 \text { months on mild } \\
\text { forms and } 12 \text { to } 18 \text { months } \\
\text { on moderate forms }\end{array}$ \\
\hline \multirow[t]{2}{*}{$\begin{array}{l}\text { Severe forms (disseminated } \\
\text { disease, CNS accomitiment, } \\
\text { respiratory failure, jaundice, } \\
\text { hemodynamic instability)- } \\
\text { inpatient }\end{array}$} & First line & $\begin{array}{l}\text { Trimethoprim/ } \\
\text { sulfametoxazole }\end{array}$ & $\begin{array}{l}\text { Trimethoprin, } 8 \text { to } \\
10 \mathrm{mg} / \mathrm{kg} \text { and } \\
\text { sulfametoxazole, } \\
40 \text { to } 50 \mathrm{mg} / \mathrm{kg}, \mathrm{IV}, \mathrm{BID} / \mathrm{QD}\end{array}$ & $\begin{array}{l}\text { Change for oral drug when it will be } \\
\text { possible }\end{array}$ \\
\hline & Alternative & Amphotericin B & $1 \mathrm{mg} / \mathrm{kg} /$ day $(\mathrm{IV})$ & \\
\hline
\end{tabular}

Source: [60]

$I V$ intravenously, $P O$ orally 
Table 4 Recommendations for management on cryptococosis in pediatric patients adapted from Perfect J, 2010

\begin{tabular}{ll}
\hline Clinical presentation & Management \\
\hline $\begin{array}{l}\text { Induction and consolidation } \\
\text { therapy for CNS and }\end{array}$ & d-AmB $(1 \mathrm{mg} / \mathrm{kg} /$ day IV) plus flucytosine \\
disseminated disease & $(100 \mathrm{mg} / \mathrm{kg} /$ day orally in four divided doses $)$ \\
& for 2 weeks \\
Non-HIV-infected, nontransplant population, followed & by therapy with fluconazole $(10-12 \mathrm{mg} / \mathrm{kg}$ per day orally $)$ \\
for 8 weeks & For d-AmB intolerant patients, either L-AmB ( $5 \mathrm{mg} / \mathrm{kg} /$ day $)$ or ABLC \\
& $(5 \mathrm{mg} / \mathrm{kg} /$ day $)$ \\
Maintenance therapy is fluconazole $(6 \mathrm{mg} / \mathrm{kg} /$ day orally) & Discontinuation of maintenance therapy in children receiving \\
HAART is poorly studied and must be individualized & Fluconazole (6-12 $\mathrm{mg} / \mathrm{kg} /$ day orally) for $6-12$ months \\
\hline
\end{tabular}

Source: [82]

$d-A m B$ deoxicholate amphotericin $\mathrm{B}, L-A m B$ liposomal amphotericin B individuals but is more frequent in immunocompromised patients mainly with HIV/AIDS who had impairment of cellular immunity [71]. The mean annual incidence of cryptococcosis in the general population in Colombia was 2.4 cases per 106 people between 1995 and 2010; in the population with human immunodeficiency virus (HIV), the incidence ranged between 3 and 3.3 cases per 103 people. [39].

Global literature has described fewer cases in children than adults [74], including those occurring in immunocompromised patients. The prevalence of Cryptococcus spp. in children with AIDS is estimated at $1 \%$ and in adults about 6-8\% [75]. The low frequency of cryptococcosis in children cannot be explained by lack of exposure to the disease; in fact, one study shows that the majority of children older than 2 years of age have serological evidence of infection by C. neoformans [73].

The clinical diagnosis of cryptococcemia is difficult as clinical signs vary greatly due to infection in different organs [76]. Previous studies have shown that patients with cryptococcemia have a high fever; then, fever with tremors and chills in immunocompromised patients may be a warning sign for suspecting cryptococcemia [77]. Meningitis and meningoencephalitis are the most common clinical manifestations [78].

Usually, cryptococcosis diagnosis is made by mycological examination of cerebrospinal fluid (CSF), tissue biopsy, sputum, or other body fluids [79]. Approximately $80 \%$ of AIDS patients and $50 \%$ of non-AIDS have fungus observed in direct examination [70]. Cryptococcus spp. isolation from the bloodstream is not rare, but few clinical/epidemiological studies have examined its role and the underlying etiological agents. Previous studies reported blood culture as an important diagnostic method for cryptococcosis in AIDS patients $[76,80]$. The ideal treatment is amphotericin B associated with 5-fluorocytosin. It is necessary to control CSF samples to certify the eradication of Cryptococcus spp. [81, 82]. A sterile culture within 2 weeks of starting treatment confirms the fungicidal action of drugs, and this is associated with therapeutic success [83].

We evaluated two articles on cryptococcosis, one in Colombia, descriptive, with a prevalence of $2.6 \%$ in patients under 16 years old [39] and the other in Uruguay, series of cases, with patients in the range of 7-13 years [38] (Appendix 3 ). Only the descriptive study cited risk factors, with HIV infection at the top (24.4\%), followed by $7.3 \%$ of autoimmune diseases, steroid use, and hematological disease, and $2.3 \%$ of kidney disease, solid tumor, and prematurity [39]. The most frequent clinical manifestations were headache (78.1\%), fever (68.8\%), nausea and vomiting (65.6\%), confusion (50\%), and meningeal signs (37.5\%); the most frequent clinical presentations were meningitis, followed by disseminated cryptococcosis $[38,39]$. Direct examination was the most used test for diagnosis, and capsular antigen detection was positive in all the cases that it was done, in serum and in CSF. Culture was positive in $89.5 \%$, with C. neoformans the most found $(94.1 \%)[38,39]$. The drug of choice was amphotericin B (93.5\%), with fluconazole as maintenance treatment $[38,39]$. Recommendation for antifungal therapy in children with cryptococcosis is described in Table 4.

\section{Mold infections}

Mold infections must be cited because of their importance in immunocompromised patients. In this population, fungi are responsible for most deaths from infections. The overall risk of death in patients with mold infections can reach 30-70\% [84]. Early diagnosis of invasive mold infections and prompt implementation of aggressive antifungal treatment have proven to be critical for patient survival. A major advancement in 
the approach for IFD in immunocompromised patients has been the international consensus definition for IFD published by the European Organization for Research and Treatment of Cancer Classification (EORTC), together with the acceptance of nonculture diagnostic techniques such as galactomannan (GM) and the accessibility to more safe and efficient antifungal therapies [85].

There are two prospective epidemiological studies published in children in LA from Chile and from Brazil in 2013. These studies evaluated the rate of IFD in children with cancer (Chile) and in children and adults with acute myeloide leukemia (AML) or myelodysplasia (MD) and underwent HSCT (Brazil). In the first, the authors aimed to identify risk factors for IFD in children with cancer, fever, and neutropenia in a prospective, multicenter study. A diagnosis of proven, probable, and possible IFD was made after episode resolution based on EORTC definitions. IFD was diagnosed in 35/604 febrile neutropenic episodes evaluated (5.8\%), of which 7 (1.2\%) were proven, $10(1.6 \%)$ probable, and $18(3.0 \%)$ possible; the authors did not mention any antifungal prophylaxis in the study. Most frequent mycosis in this population was candidiasis, followed by mold infections: invasive aspergillosis (IA) and zygomycoses [45]. In the second study, the authors observed a higher incidence of fusariosis in allogeneic HCT cohort (5.2\%) followed by IA and candidiasis. In study which includes mainly adult population more than $70 \%$ were receiving antifungal prophylaxis with fluconazole [42].

Aspergillus spp. are ubiquitous fungi consistently documented as some of the most prevalent airborne molds. Conidia of Aspergillus species are often found in fireproofing or building material and are dispersed by ventilation systems into indoor air, including air within hospitals [44]. Infection is usually initiated by inhalation of airborne conidia and can cause a spectrum of clinical syndromes in the lung like IA, the most common in immunocompromissed patient particularly those with prolonged and severe neutropenia due to cancer chemotherapy, high-dose corticosteroids, or broad-spectrum antibiotics [86].
Some aspects of IA care appear to be the same for adults and children, but there are important basic epidemiologic, pathophysiologic, and treatment differences in IA in children and adults. Unfortunately, only a few small studies of aspergillosis in children have been reported in literature [84, 86-91], none performed in LA. As shown by adult studies, pulmonary IA is the clinical site most commonly identified $[84,86]$. The cutaneous presentation of aspergillosis appears to be more common in children, from $13.7 \%(19 / 139 \mathrm{pa}-$ tients) in a study published by Burgos in 2008 to $20 \%$ (13/ 66 patients) in St Jude review and $41 \%$ (16/39 patients) in Toronto study [84, 86, 87].

Early diagnosis is important to patient outcome, and the clinician should have a high index of suspicion, especially in patients with underlying malignancies who are neutropenic with a prolonged fever despite systemic antimicrobial therapy. Numerous diagnostic approaches should be utilized. Computed tomography (CT) chest is more sensitive and specific than traditional chest radiographs in neutropenic patients and is considered the best method of diagnosis for invasive pulmonary aspergillosis. Nevertheless, it is important to note that the incidence of classic radiological findings is lower in pediatric patients than in adults; central cavitation of small nodules was not so frequent in pediatric series [84]. Other tools like galactomanan index (GMI) are useful for early diagnosis and became positive before the images. The specificity of the test may be lower in pediatric than adult patients [92] and further validation of the GMI for the early diagnosis of IA in high-risk pediatric patients is warranted. The recommend treatment by IDSA is voriconazole (evidence AI) as the same for adult [93]. Recommendation for antifungal therapy in children with aspergillosis is described in Table 5.

Fusarium is a genus of widely distributed saprophytic molds capable of causing disease in plants, animals, and humans [94]. Invasive fusariosis is uncommon and predominately affects immunocompromised hosts, particularly those with underlying hematological malignancy, neutropenia, and
Table 5 Recommendations for management on invasive aspergillosis in pediatric patients adapted from Groll AH, 2014

\begin{tabular}{|c|c|c|c|}
\hline Drug & & Dosage & Duration \\
\hline \multirow[t]{4}{*}{ First line } & Voriconazole (AI) & $\begin{array}{l}\text { Children aged } 2-12 \text { or } 12-14 \text { years old and } \\
\text { weighing < } 50 \mathrm{~kg} \text { : IV: (day } 1): 8 \mathrm{mg} / \mathrm{kg} \\
\text { twice daily and after } 9 \mathrm{mg} / \mathrm{kg} \text { twice daily } \\
\text { or PO: } 9 \mathrm{mg} / \mathrm{kg} \text { twice daily }\end{array}$ & \multirow[t]{4}{*}{6 to 12 weeks } \\
\hline & & $\begin{array}{l}\text { Children aged } \geq 14 \text { years old or } 12-14 \text { years old } \\
\text { weighing } \geq 50 \mathrm{~kg}: \mathrm{IV} \text { : (day } 1): 4 \mathrm{mg} / \mathrm{kg} \\
\text { twice daily and after } 6 \mathrm{mg} / \mathrm{kg} \text { twice daily } \\
\text { or PO: } 200 \mathrm{mg} \text { twice daily orally plus TDM }\end{array}$ & \\
\hline & L-AmB (B-I) & $3 \mathrm{mg} / \mathrm{kg} /$ day (IV) _ once a day & \\
\hline & Lipidic complex AmB (B-II) & $5 \mathrm{mg} /$ day (IV) once a day & \\
\hline
\end{tabular}

Source: [93]

$I V$ intravenously, $P O$ orally, $T D M$ therapeutic drug monitoring 
glucocorticoid exposure [95]. Although fusariosis is frequent in Brazil and associated with a very high mortality rate, to our knowledge, the literature in pediatric patients is scarce and there is no other data from children in LA.

\section{Conclusions}

IFD are important causes of morbidity and mortality. The knowledge of the incidence and prevalence in some regions is very important as geographic differences can interfere in the epidemiology of the species. Limited data in pediatric setting is available in South America. Candida albicans remains as the most frequent species of yeast isolated from bloodstream infections, but over the years, the numbers of candidemias caused by non-albicans species has been increasing. C. parapsilosis is more prevalent in younger children. PCM is an important mycose especially in Brazil with high rate of mortality and must be considered in endemic areas. Cryptococcis occurred in association with HIV infection, and the CNS clinical presentation is the most common. Other mold infection like Aspergillus spp., Fusarium spp., and zygomycosis must be considered especially in imunocompromised patients. More clinical studies must be done in pediatrics regarding to epidemiology, risk factors, diagnosis, prevention, therapy, and prognosis.

\section{Compliance with Ethical Standards}

Conflict of Interest Fabianne Carlesse, Adriana Maria Paixão de Sousa da Silva, and Maria Elena Santolaya declare that they have no conflict of interest.

Human and Animal Rights and Informed Consent This article does not contain any studies with human or animal subjects performed by any of the authors.

\section{References}

1. Abelson JA, Moore T, Bruckner D, Deville J, Nielson K. Frequency of fungemia in hospitalized pediatric inpatients over 11 years at a tertiary care institution. Pediatrics. 2005;116:61-7.

2. Even C, Bastuji-Garin S, Hicheri Y, et al. Impact of invasive fungal disease on the chemotherapy schedule and event-free survival in acute leukemia patients who survived fungal disease: a case-control study. Haematologica. 2011;96:337-41.

3. Martino R, Kerguelen A, Valcarcel D, et al. Reduction of infection related mortality after allogeneic PBSCT from HLA-identical siblings: longitudinal analysis from 1994 to 2008 at a single institution. Bone Marrow Transplant. 2011;46:690-701

4. Creutzig U, Zimmermann M, Reinhardt D, Dworzak M, Stary J, Lehrnbecher T. Early deaths and treatment-related mortality in children undergoing therapy for acute myeloid leukemia: analysis of the multicenter clinical trials AML-BFM 93 and AML-BFM 98. J Clin Oncol. 2004;22(21):4384-93.
5. Pagano L, Caira M, Candoni A, et al. The epidemiology of fungal infections in patients with hematologic malignancies: the SEIFEM2004 study. Haematologica. 2006;91:1068-75.

6. Watson RS, Carcillo JA, Linde-Zwirble WT, Clermont G, Lidicker $\mathrm{J}$, Angus DC. The epidemiology of severe sepsis in children in the United States. Am J Respir Crit Care Med. 2003;167(5):695-701.

7. Prentice HG, Kibbler CC, Prentice AG. Towards a targeted, riskbased, antifungal strategy in neutropenic patients. Br J Haematol. 2000;110:273-84.

8. Nucci M, Queiroz-Telles F, Alvarado-Matute T, Tiraboschi IN, Cortes J, et al. Epidemiology of candidemia in Latin America: a laboratory-based survey. PLoS ONE. 2013;8(3):1-7.

9. Storti LR, Pasquale G, Scomparim R, Galastri AL, Alterthum F, Gambale W, et al. Candida spp. Isolated from inpatients, the environment, and health practitioners in the pediatric unit at the Universitary hospital of the Jundiaí medical college, state of São Paulo, brazil. Rev Soc Bras Med Trop. 2012;45(2):225-31.

10. Yamamoto ACA, de Paula CR, Dias LB, Tadano T, Martins ER, Amadio JVRS, et al. Epidemiological and clinical characteristics of nosocomial candidiasis in university hospitals in Cuiabá - Mato Grosso. Braz Rev Iberoam Micol. 2012;29(3):164-8.

11. Bonfietti LX, Szeszs MW, Chang MR, Martins MA, Pukinskas SRBS, Nunes MO, et al. Ten-year study of species distribution and antifungal susceptibilities of Candida bloodstream isolates at a Brazilian tertiary hospital. Mycopathologia. 2012;174:389-96.

12. De Almeida AA, Mesquita CSS, Svidzinski TIE, De Oliveira KMP. Antifungal susceptibility and distribution of Candida spp. Isolates from the university hospital in the municipality of dourados, state of mato grosso do Sul, Brazil. Rev Soc Bras Med Trop. 2013;46(3): $335-9$.

13. Colombo AL, Garnica M, Camargo LFA, Da Cunha CA, Bandeira $\mathrm{AC}$, Borghi D, et al. Candida glabrata: an emerging pathogen in Brazilian tertiary care hospitals. Med Mycol. 2013;51(1):38-44.

14. Ruiz LDS, Khouri S, Hahn RC, da Silva EG, de Oliveira VKP, Gandra RF, et al. Candidemia by species of the Candida parapsilosis complex in Children's hospital: prevalence, biofilm production and antifungal susceptibility. Mycopathologia. 2013;175:231-9.

15. Wille MP, Guimarães T, Furtado GHC, Colombo AL. Historical trends in the epidemiology of candidaemia: analysis of an 11-year period in a tertiary care hospital in Brazil. Mem Inst Oswaldo Cruz. 2013;108(3):288-92.

16. Moretti ML, Trabasso P, Lyra L, Fagnani R, Resende MR, Cardoso LGO, et al. Is the incidence of candidemia caused by Candida glabrata increasing in Brazil? Five-year surveillance of Candida bloodstream infection in a university reference hospital in southeast Brazil. Med Mycol. 2013;51:225-30.

17. Santolaya ME, Queiroz-Telles F, Matute TA, et al. Recommendations for the management of candidemia in children in Latin America. Rev Iberoam Micol. 2013;30 Suppl 1:171-8.

18. Hoffmann-Santos HD, Paula CR, Yamamoto ACA, Tadano T, Hahn RC. Six-year trend analysis of nosocomial candidemia and risk factors in Two intensive care hospitals in mato grosso, Midwest region of brazil. Mycopathologia. 2013;176:409-15.

19. Tinoco-Araujo JE, Araújo DFG, Barbosa PG, Santos PSDS, Medeiros AMC. Invasive candidiasis and oral manifestations in premature newborns. Einstein, São Paulo, Braz. 2013;11(1):71-5.

20. Ruiz LS, Montelli AC, Sugizaki MF, Da Silva EG, Batista GCM, Moreira D, et al. Outbreak of fungemia caused by Candida parapsilosis in a neonatal intensive care unit: Molecular investigation through microsatellite analysis. Rev Iberoam Micol. 2013;30(2):112-5.

21. Santolaya ME, Matute TA, Telles FQ, Colombo AL, Zurita J, Tiraboschi IN, et al. Recommendations for the management of candidemia in neonates in Latin America. Rev Iberoam Micol. 2013;30(3):158-70. 
22. Santolaya ME, Alvarado T, Queiroz-Telles F, Colombo AL, Zurita $\mathrm{J}$, Tiraboschi IN, et al. Active surveillance of candidemia in children from Latin America: a key requirement for improving disease outcome. Pediatr Infect Dis J. 2013;33(2):40-4.

23. Maldonado NA, Cano LE, De Bedout C, Arbeláez CA, Roncancio G, Tabares AM, et al. Association of clinical and demographic factors in invasive candidiasis caused by fluconazole-resistant Candida species: a study in 15 hospitals, Medellín, Colombia 2010-2011. Diagn Microbiol Infect Dis. 2014;79(2):280-6.

24. Cortés JA, Reyes P, Gómez CH, Cuervo SI, Rivas P, Casas CA, et al. Clinical and epidemiological characteristics and risk factors for mortality in patients with candidemia in hospitals from Bogotá, Colombia. Braz J Infect Dis. 2014;18(6):631-7.

25. Quindós G. Epidemiology of candidaemia and invasive candidiasis. A changing face. Rev Iberoam Micol. 2014;31(1):42-8.

26. Oliveira VKP, Ruiz LS, Oliveira NAJ, Moreira D, Hahn RC, Melo ASA, et al. Fungemia caused by Candida species in children's public hospital in the city of Sao Paulo, Brazil: study in the period 20072010. Rev Inst Med Trop Sao Paulo. 2014;56(4):301-5.

27. Da Costa VG, Quesada RMB, Abe ATS, Furlaneto-Maia L, Furlaneto MC. Nosocomial bloodstream Candida infections in a tertiary-care hospital in south Brazil: a 4-year survey. Mycopathologia. 2014;178:243-50.

28. Izquierdo G, Santolaya ME. Candidiasis invasoras en recién nacidos: diagnóstico, tratamiento y prevención. Rev Chil Infectol. 2014;31(1):73-83.

29. Batista GCM, Krebs VLJ, Ruiz LS, Auler ME, Hahn RC, Paula CR. Oral colonization: a possible source for candidemia in lowweight neonates. J Mycol Med. 2014;24(2):81-6.

30. Matos WB, Santos GMC, Silva VEB, Gonçalves EGR, Silva AR. Paracoccidioidomycosis in the state of Maranhão, Brazil: geographical and clinical aspects. Rev Soc Bras Med Trop. 2012;45(3):385-9.

31. Bellissimo-Rodrigues F, Bollela VR, Da Fonseca BAL, Martinez R. Endemic paracoccidioidomycosis: relationship between clinical presentation and patients' demographic features. Med Mycol. 2012;51:313-8.

32. Marques APDC, Oliveira SMVL, Rezende GR, Melo D, Fernandes-Fitts SM, Pontes ERJC, et al. Evaluation of Paracoccidioides brasiliensis infection by gp 43 intradermal test in rural settlements in central-west Brazil. Mycopathologia. 2013; 176:41-7.

33. Braga GM, Hessel G, Pereira RM. Hepatic involvement in pediatric patients with paracoccidioidomycosis: a clinical and laboratory study. Mycopathologia. 2013;176:279-86.

34. Fabris LR, Andrade UV, Santos AF, Marques APDC, Oliveira SMVL, Mendes RP, et al. Decreasing prevalence of the acute/ subacute clinical form of paracoccidioidomycosis in Mato Grosso do Sul State, Brazil. Rev Inst Med Trop Sao Paulo. 2014;56(2): $121-5$.

35. Taicz M, Rosanova MT, Bes D, Lisdero ML, Iglesias V, Santos P, et al. Paracoccidioidomicosis en pediatría: descripción de 4 casos. Rev Iberoam Micol. 2014;31(2):141-4.

36. Vieira GD, Alves TC, Lima SMD, Camargo LMA, de Sousa CM. Paracoccidioidomycosis in a western Brazilian Amazon State: clinical-epidemiologic profile and spatial distribution of the disease. Rev Soc Bras Med Trop. 2014;47(1):63-8.

37. Magalhães EMS, Ribeiro CF, Dâmaso CS, Coelho LFL, Silva RR, Ferreira EB, et al. Prevalence of paracoccidioidomycosis infection by intradermal reaction in rural areas in alfenas, minas gerais, Brazil. Rev Inst Med Trop Sao Paulo. 2014;56(4):281-5.

38. Quian J, Gutiérrez S, González V, Sánchez M, Abayian M. Meningitis por Cryptococcus neoformans en niños y adolescentes infectados por virus de la inmunodeficiencia humana. Rev Chil Infectol. 2012;29(5):554-7.
39. Lizarazo J, Escandón P, Agudelo CI, Castañeda E. Cryptococcosis in Colombian children and literature review. Mem Inst Oswaldo Cruz. 2014;109(6):797-804.

40. Fernández M, Cattana M, Rojas F, Sosa MA, Aguirre C, Vergara M, et al. Especies de Aspergillus en ambientes hospitalarios con pacientes pediátricos en estado crítico. Rev Iberoam Micol. 2014;31(3): 176-81.

41. Moral LL, Tiraboschi IN, Schijman M, Bianchi M, Guelfand L, Cataldi S. Fungemias en hospitales de la Ciudad de Buenos Aires, Argentina. Rev Iberoam Micol. 2012;29(3):144-9.

42. Nucci M, Garnica M, Gloria AB, Lehugeur DS, Dias VCH, Palma $\mathrm{LC}$, et al. Invasive fungal diseases in haematopoietic cell transplant recipients and in patients with acute myeloid leukaemia or myelodysplasia in Brazil. Clin Microbiol Infect. 2013;19(8):745-51.

43. Rabagliati R, Santolaya ME. Profilaxis antifúngica en niños y adultos sometidos a trasplante de órganos sólidos y de precursores hematopoyéticos. Rev Chil Infect. 2012;29(1):11-8.

44. Mesquita-Rocha S, Godoy-Martinez PC, Gonçalves SS, Urrutia MD, Carlesse F, Seber A, et al. The water supply system as a potential source of fungal infection in paediatric haematopoietic stem cell units. BMC Infect Dis. 2013;13(1):289.

45. Villarroel M, Avilés C, Silva P, et al. Risk factors associated with invasive fungal disease in children with cancer and febrile neutropenia. A prospective, multicenter evaluation. Ped Infect Dis J. 2010;29:816-21.

46. Leroy O, Gangneux JP, Montravers P, et al. Epidemiology, management, and risk factors for death of invasive Candida infections in critical care: a multicenter, prospective, observational study in France (2005 - 2006). Crit Care Med. 2009;37:1612-8.

47. Zaoutis TE, Coffin SE, Chu JH, et al. Risk factors for mortality in children with candidemia. Pediatr Infect Dis J. 2005;24:736-9.

48. França JC, Ribeiro CE, Queiroz-Telles F. Candidemia in a Brazilian tertiary care hospital: incidence, frequency of different species, risk factors and antifungal susceptibility. Rev Soc Bras Med Trop. 2008;41:23-8.

49. Nucci M, Queiroz-Telles F, Tobón AM, Restrepo A, Colombo AL. Epidemiology of opportunistic fungal infections in Latin America. Clin Infect Dis. 2010;51(5):561-70.

50. Pfaller MA, Diekema DJ, Gibbs DL, et al. Results from the ARTEMIS DISK global antifungal surveillance study, 1997 to 2007: a 10.5-year analysis of susceptibilities of candida species to fluconazole and voriconazole as determined by CLSI standardized disk diffusion. J Clin Microbiol. 2010;48(4):1366-77.

51. Colombo AL, Guimarães T. Epidemiologia das infecções hematogênicas por Candida spp. Rev Soc Bras Med Trop. 2003;36:599-607.

52. Paula CR, Montelli AC, Ruiz LS, Batista GCM, Matsumoto FE, Volpearnoni M, et al. Infecção hospitalar fúngica: experiência em hospitais públicos de São Paulo. Prática Hosp. 2007;52:63-6.

53. Steinbach WJ, Roilides E, Berman D, et al. International Pediatric Fungal Network. Results from a prospective, international, epidemiologic study of invasive candidiasis in children and neonates. Pediatr Infect Dis J. 2012;31:1252-7.

54. Colombo AL, Nucci M, Salomão R, Branchini ML, Richtmann R, Derossi A, et al. High rate of non-albicans candidemia in Brazilian tertiary care hospitals. Diagn Microbiol Infect Dis. 1999;34:281-6.

55. Yapar N, Pullukcu H, Avkan-Oguz V, Sayin-Kutlu S, Ertugrul B, Sacar S, et al. Evaluation of species distribution and risk factors of candidemia: a multicenter case-control study. Med Mycol. 2011;49: 26-31.

56. Horn DL, Neofytos D, Anaissie EJ, et al. Epidemiology and outcomes of candidemia in 2019 patients: data from the prospective antifungal therapy alliance registry. Clin Infect Dis. 2009;48:1695703.

57. Pappas PG, Kauffman CA, Andes D, Benjamin DK, Calandra TF, Edwards JE, et al. Clinical practice guidelines for the management 
of candidiasis: 2009 update by the infectious diseases society of america. Clin Infect Dis. 2009;41:503-35.

58. Restrepo A, Gómez BL, Tobón A. Paracoccidioidomycosis: Latin America's own fungal disorder. Curr Fungal Infect Rep. 2012;6:303-11.

59. Lacaz CS. Paracoccidioidomicose. In: Lacaz CS, Porto E, Martins JEC, Heins-Vaccari EM, Melo NT, editors. Tratado de micologia medica lacaz. Sao Paulo: Sarvier; 2002. p. 639-729.

60. Shikanai-Yasuda MA, Telles-Filho FQ, Mendes RP, Colombo AL, Moretti ML. Consenso em paracoccidioidomicose. Rev Soc Bras Med Trop. 2006;39:297-310.

61. Santos WA, Silva BM, Passos ED, Zandonade E, Falqueto A. Association between smoking and paracoccidioidomycosis: a case-control study in the State of Espirito Santo, Brazil. Cad Saude Publica. 2003;19:245-53.

62. Coutinho ZF, Silva D, Lazera M, Petri V, Oliveira RM, Sabroza PC, et al. Paracoccidioidomycosis mortality in Brazil. Cad Saúde Públicas. 2002;18:1441-54.

63. Franco M. Host-parasite relationships in paracoccidioidomycosis. J Med Vet Mycol. 1987;27:5-18.

64. Franco M, Montenegro MP, Marques AS, Dillon NL, Mota NG. Paracoccidioidomycosis: a recently proposed classification of its clinical forms. Rev Soc Bras Med Trop. 1987;20:129-32.

65. Verli FD, Marinho AS, Souza SC, Figueiredo MAS, Yurgel LS. Clinical epidemiologic profile of paracoccidioidomycosis at the stomatology department of São lucas hospital, pontificia universidade católica of Rio grande do Sul. Rev Soc Bras Med Trop. 2005;38:234-7.

66. Del-Negro G, Lacaz CS, Fiorillo AM, editors. Paracoccidioidomicose (Blastomicose sul-americana). SarvierEdusp, Sao Paulo, 1982.

67. Pereira RM, Bucaretchi F, Barison EM, Hessel G, Tresoldi AT. Paracoccidioidomycosis in children: clinical presentation, followup and outcome. Rev Inst Med Trop S Paulo. 2004;46:127-31.

68. Travassos LR, Puccia R, Cisalpino P, Taborda C, Rodrigues EG, Rodrigues $\mathrm{M}$, et al. Biochemistry and molecular biology of the main diagnostic antigen of Paracoccidioides brasiliensis. Arch Med Res. 1995;26:297-304.

69. Cermeño J, Cermeño J, Godoy G, Hernández I, Orellán Y, Blanco $\mathrm{Y}$, et al. Epidemiological study of paracoccidioidomycosis and histoplasmosis in a suburb of San Félix city, Bolívar State. Venezuela Invest Clin. 2009;50:2013-20.

70. Perfect JR, Casadevall A. Cryptococcosis. Infect Dis Clin North Am. 2002;16:837-74.

71. Casadevall A, Perfect JR. Cryptococcus neoformans. Washington, DC: American Society for Microbiology; 1998.

72. Moretti ML, Resende MR, Lazéra MS, Colombo AL, ShikanaiYasuda MA. Guidelines in cryptococcosis-2008. Rev Soc Bras Med Trop. 2008;41:524-44.

73. Goldman DL, Khine H, Abadi J, Lindenberg DJ, Pirofski LA, Niang R, et al. Serologic evidence for Cryptococcus neoformans infection in early childhood. Pediatrics. 2001;107(5):1-6.

74. Meiring ST, Quan VC, Cohen C, Dawood H, Karstaedt AS, McCarthy KM, et al. A comparison of cases of paediatric-onset and adult-onset cryptococcosis detected through population-based surveillance, 2005-2007. AIDS. 2012;26:2307-14.

75. Abadi J, Nachman S, Kressel AB, Pirofski L. Cryptococcosis in children with AIDS. Clin Infect Dis. 1999;28:309-13.

76. Rozenbaum R, Gonçalves AJR. Clinical epidemiological study of 171 cases of cryptococcosis. Clin Infect Dis. 1994;18(3):369-80.

77. Tsujisaki RAS, Paniago AMM, Lima Júnior MSC, Alencar DSO, Spositto FLE, Nunes MO, et al. First molecular typing of cryptococcemia-causing Cryptococcus in central-west brazil. Mycopathologia. 2013;176:267-72.

78. Favalessa OC, De Paula DAJ, Dutra V, Nakazato L, Tadano T, Lazera MS, et al. Molecular typing and in vitro antifungal susceptibility of Cryptococcus spp from patients in Midwest Brazil. J Infect Dev Countries. 2014;8(8):1037-43.

79. Severo CB, Pinto GLF, Sotilli J, Garcia MR, Gazzoni AF, Oliveira FM, et al. Cryptococcuria as manifestation of disseminated cryptococcosis: Staib agar as a selective identification medium. Mycoses. 2011;54(6):760-6.

80. Monteiro DU, Brum TF, Noal CB, Righi RA, Santos ER, Oliveira LTO, et al. Prevalencia de candida e cryptococcus em hemoculturas oriundas de pacientes do hospital universitario de santa maria, RS (HUSM) no ano de 2006. Saude (Santa Maria). 2011;37(2):81-2.

81. Brouwer AE, Rajanuwong A, Chierakul W, Griffin GE, Larsen RA, White NJ, et al. Combination antifungal therapies for HIV associated cryptococcal meningitis: a randomised trial. Lancet. 2004;363: 1764-7.

82. Perfect JR, Dismukes WE, Dromer F, Goldman DL, Graybill JR, Hamill RJ, et al. Clinical practice guidelines for the management of cryptococcal disease: 2010 . Update by the infectious diseases society of america. Clin Infect Dis. 2010;50:291-322.

83. van der Horst CM, Saag MS, Cloud GA, Hamill RJ, Graybill JR, Sobel JD, et al. Treatment of cryptococcal meningitis associated with the acquired immunodeficiency syndrome. N Engl J Med. 1997;337:15-21.

84. Burgos A, Zaoutis TE, Dvorak CC, Hoffman JA, Knapp KM, Nania JJ, et al. Pediatric invasive Aspergillosis: a multicenter retrospective analysis of 139 contemporary cases. Pediatrics. 2008;121: 1286-94.

85. De Pauw B, Walsh TJ, Donnelly JP, et al. Revised definitions of invasive fungal disease from the european organization for research and treatment of cancer/invasive fungal infections cooperative group and the national institute of allergy and infectious diseases mycoses study group (EORTC/MSG) consensus group. Clin Infect Dis. 2008;46:1813-21.

86. Abbasi S, Shenep JL, Hughes WT, Flynn PM. Aspergillosis in children with cancer: a 34-year experience. Clin Infect Dis: Off Publ Infect Dis Soc Am. 1999;29:1210-9.

87. Walmsley S, Devi S, King S, et al. Invasive Aspergillus infections in a pediatric hospital: a ten year review. Pediatr Infect Dis J. 1993;12:673-82.

88. Groll AH, Kurz M, Schneider W, Witt V, Schmidt H, Schneider M, et al. Five year-survey of invasive aspergillosis in a paediatric cancer centre. Epidemiology, management and long-term survival. Mycoses. 1999;42:431-42.

89. Steinbach WJ. New findings and unique aspects in pediatric aspergillosis. Med Mycol. 2005;43:261-5.

90. Zaoutis TE, Heydon K, Chu JH, Walsh TJ, Steinbach WJ. Epidemiology, outcomes, and costs of invasive aspergillosis in immunocompromised children in the United States, 2000. Pediatrics. 2006;117(4):711-6.

91. Han SB, Kim S, Bae EY, Lee JW, Yoon J, Chung N, et al. Clinical features and prognosis of invasive pulmonary Aspergillosis in Korean children with hematologic/oncologic diseases. J Korean Med Sci. 2015;30(12):1121-8.

92. Herbrecht R, Letscher-Bru V, Oprea C, et al. Aspergillus galactomannan detection in the diagnosis of invasive aspergillosis in cancer patients. J Clin Oncol. 2002;7:1898-906.

93. Groll $\mathrm{AH}$ et al. Fourth European Conference on Infections in Leukaemia (ECIL-4): guidelines for diagnosis, prevention, and treatment of invasive fungal diseases in paediatric patients with cancer or allogeneic haemopoietic stem-cell transplantation. Lancet Oncol. 2014;15(8):327-40.

94. Nelson PE, Dignani MC, Anaissie EJ. Taxonomy, biology, and clinical aspects of Fusarium species. Clin Microbiol Rev. 1994;7(4):479-504.

95. Nucci M, Marr KA, Queiroz-Telles F, Martins CA, Trabasso P, Costa S, et al. Fusarium infection in hematopoietic stem cell transplant recipients. Clin Infect Dis. 2004;38(9):1237-42. 